\title{
Subglottic Cancer pT1 TNM Finding v6 and v7
}

National Cancer Institute

\section{Source}

National Cancer Institute. Subglottic Cancer pT1 TNM Finding v6 and v7. NCI Thesaurus. Code C64717.

Subglottic cancer in which the tumor is limited to the subglottis. (from AJCC 6th and 7th Eds.) 